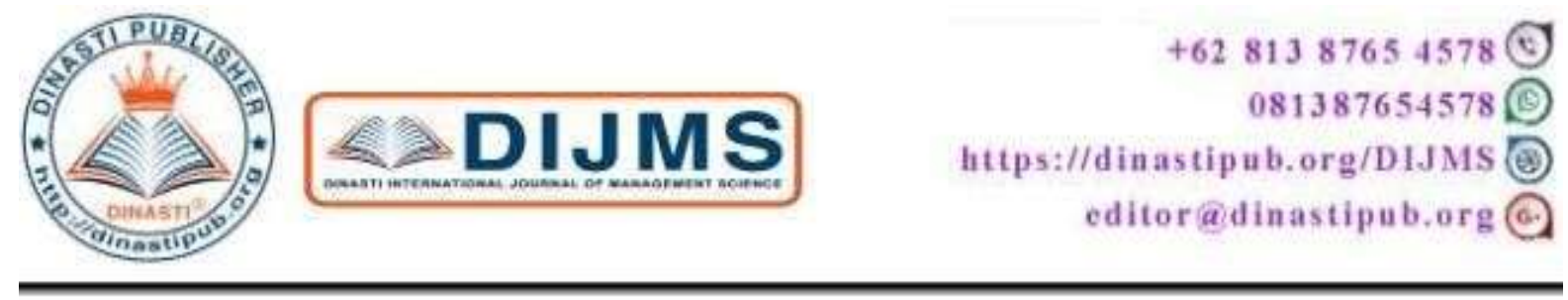

\title{
THE INFLUENCE OF CUSTOMER RELATIONSHIP MANAGEMENT, CUSTOMER SATISFACTION QUALITY OF SERVICE AND CUSTOMER LOYALTY
}

(Empirical Study On Corporate Travel Organizers Umrah and Hajj PT. Travel Albadriyah)

\section{Subaebasni $^{1}$, Henny Rinawati ${ }^{2}$, Anoesyirwan Moeins ${ }^{3}$}

1) Faculty of Economics and Business, University Persada Indonesia YAI, Jakarta, Indonesia

2) Faculty of Economics and Business, University Persada Indonesia YAI, Jakarta, Indonesia

3) Faculty of Economics and Business, University Persada Indonesia YAI, Jakarta, Indonesia

\begin{tabular}{|c|c|}
\hline $\begin{array}{l}\text { ARTICLE INFORMATION } \\
\text { Received: 30/10/2019 } \\
\text { Revised: 04/11/2019 } \\
\text { Issued: 06/11/2019 }\end{array}$ & $\begin{array}{l}\text { Abstract: Every company should be able to } \\
\text { understand the behavior of consumers in the target } \\
\text { market because the survival of the company as an } \\
\text { organization that seeks to meet the needs and desires } \\
\text { of consumers rely heavily on the behavior of } \\
\text { consumers. Through an understanding of consumer } \\
\text { behavior, the management company can develop } \\
\text { appropriate strategies and programs to take advantage } \\
\text { of existing opportunities and outperform their } \\
\text { competitors. Therefore, the quality of good service and } \\
\text { build relationships with customers able to accomplish } \\
\text { the goals of the company. It certainly needs to be an } \\
\text { active part of all employees and those involved in the } \\
\text { provision of services. (MORA, 2017). Based on the } \\
\text { analysis and discussion that has been described on the } \\
\text { effect of customer relationship management, service } \\
\text { quality, and customer satisfaction to customer loyalty } \\
\text { in Corporate Travel Organizers Umrah and Hajj PT. } \\
\text { Travel Albadriyah, it can be concluded that customer } \\
\text { relationship management, service quality, and } \\
\text { customer satisfaction proved to influence jointly on } \\
\text { customer loyalty Corporate Travel Organizers Umrah } \\
\text { and Hajj PT. Travel Albadriyah. As this study is } \\
\text { descriptive and verification, using the survey method. } \\
\text { Keywords: Customer Satisfaction, Customer Loyalty, } \\
\text { Customer Relationship Management. }\end{array}$ \\
\hline
\end{tabular}




\section{INTRODUCTION}

Hajj and Umrah is the dream of every Muslim. Each of the pilgrimage seasons came pouring Muslims from across the country to the House to perform the pilgrimage. Hajj and Umrah as pillars of Islam that the fifth was not only aimed to increase piety and values of spiritual culprit, but also save a huge economic potential, the public interest Indonesian Muslims to perform the pilgrimage to the holy land of Mecca is the highest compared with other countries in the world, every year there is an increase, although the government through the Minister of Religion No. 6 of 2010, have increased the initial deposit for regular pilgrims from $\mathrm{Rp} 20$ million to $\mathrm{Rp} 25$ million, and a special pilgrimage from USD 3,000 to USD 4,000 .

Up to now, there are 670 Hajj and Umrah travel companies listed on the Operator Director General Hajj and Umrah until 2016, scattered in various areas in the corners of the country either PIHK (Hajj Special) and PPIU (Organizer Worship Umrah Services). The role of Umrah and Hajj Travel Agents Lodging become very important for implementing special Hajj and Umrah, given the very high value of worship, and its implementation which is outside Indonesia.

The demand for comfort in the Hajj and Umrah left entirely to the Umrah and Hajj Travel Agents Special. Associated with the high cost of Hajj and Umrah, the service user must Umrah and Hajj Travel Agents Special will be very disappointed if the service provided does not correspond to their expectations, thereby reducing their comfort in worship. Consumers would expect outstanding service and by the value of the money, they spend.

Thus, every company must be able to understand the behavior of consumers in the target market, because the survival of the company as an organization that seeks to meet the needs and desires of consumers rely heavily on the behavior of consumers. Through an understanding of consumer behavior, the management company can develop appropriate strategies and programs to take advantage of existing opportunities and outperform their competitors

\section{LITERATURE REVIEW \\ Customer loyalty}

Oliver (1999: 34) points out the definition of loyalty is as follows:

"A deeply held commitment to rebuy or patronize a preferred product/service consistently in the future. Thereby causing repetitive same-brand or same brand-set purchasing, despite situational influences and marketing efforts having the potential to cause switching behavior ". That is, loyalty is a very deep commitment to repurchase or subscribe to a product/service that is favored consistently in the future. Thereby causing the repetition of the same brand or purchase a set of the same brand, despite situational influences and marketing efforts have the potential to cause a change in behavior.

In measuring loyalty, Zeithaml et al. (2006: 38) states with some attributes, namely, (1) Saying positive things about the company to others. (2) To recommend the company to others who ask for advice. (3) Considering that the company is the first choice in the purchase of services. (4) Doing more business with the company or the purchase of the next few years.

(5) Likewise, dissatisfied customers often do not make an effort to move to another company because he believes that moving companies another same result. 
According to Robinette (2001: 13) factors that affect customer loyalty are:

a) Attention.

b) Trust.

c) Protection.

d) Accumulative satisfaction.

Consumer loyalty is generally understood as a concept that emphasizes the guidance of the purchase (Swastha, 2002: 74).

\section{Customer Relationship Management}

Kustini (2017: 31) argues customer relationship management (Customer Relationship Management or CRM) is a type of management that specifically discusses the theory about the handling of the relationship between the company and its customers to increase the company's value in the eyes of customers.

According to Storbacka and Lehtinen (2001: 4), there are three concepts of customer relationship management (customer relationship management). The first concept is the creation of customer value that aims not only to maximize revenues from a single transaction but a competitive advantage not only by price but also based on the ability of providers to help customers generate value for themselves and to build long-term relationships with customers. The second concept is to look at the product as a process, in this case, the difference between the goods and services does not matter anymore. Products are seen as an entity that includes an exchange between processes that run the provider with the process being undertaken by the customer. Through this exchange provider competence partially transferred to the customer value creation. Because of that product differentiation becomes a differentiation process that opens limitless opportunities that produce a wide range of relationships. The third concept is the responsibility of the provider.

Here is a brief explanation of CRM programs:

a) Continuity Marketing Programs.

b) One to One Marketing Programs.

c) Partnering Programs.

\section{Service quality}

According to Kotler and Keller (2012: 356) "Service is any act or performance that one party can offer to another that is essentially intangible and does not result in the ownership in anything", or it can be said that the ministry acts or activities offered by the one party to another that is essentially intangible and does not cause the ownership of anything. In reality, it is not easy to distinguish a product as goods or services appropriate for their complementarity between the two. Five categories can differentiate services and products:

a) Pure tangible good or pure product.

b) Tangible good with Accompanying services or products that include product offerings services performed by the company accompanied by one or two services.

c) hybrid

d) Major service with minor Accompanying goods and service

e) Pure service. 


\section{Customer satisfaction}

Customer satisfaction is one of the main purposes of why businesses exist and are present amid the customer's life. Increased customer satisfaction leads to business growth potential short term and long term. While customer dissatisfaction can raise some business risks, including the transfer of customer consumption to a competitor.

Knowing the customer's perception of satisfaction is very important, to avoid gaps (gap) between the company and customer perception. According to Supranto (2001: 224), customer satisfaction is determined by the quality of the goods or services so that the customer's desired quality assurance a top priority for every company, which is currently used as a benchmark in particular competitive advantage of companies.

The customer expects to surrender which offers have the highest value. Customers want maximum value, the search costs and limited by lack of knowledge, mobility, and earnings. They form an expectation of value and act on it. The fact of whether an offer meets expectations will affect the value of satisfaction and likelihood to repurchase.

Wilkie (1994: 27) states that there are four dimensions of customer satisfaction, namely:

a) Expectations.

b) Performance.

c) Comparison.

d) Confirmation / disconfirmation

\section{Framework}

To retain customers, a company needs to have a good relationship through communication. For that, we need a proper way for the company to know its customers better, to serve them better anyway. One way to establish a relationship with the customer is to build a Customer Relationship Management (CRM).

The service industry has developed more rapidly and became one of the industries that put forward the elements of service in the business. Quality of service is one of the essential elements to be considered for the customer to use the service. The main objective is to establish the quality of service and retain customers to remain loyal.

Competition increasingly competitive business today requires every company to focus on customer satisfaction as a primary goal. This is caused by the increasing number of companies offering products/services in kind so that the consumer, in this case, has a varied selection. This requires a greater effort for any company in ensuring that customers remain satisfied and eventually became loyal customers.

Customer loyalty has a strategic role in a company for customer loyalty is very influential on the achievement of future earnings. This is because customers who are loyal to the company's tendency to not think about the price. Also, the promotional costs can be reduced in such a way to remember the loyal customers no longer need the exposure information in the form of promotion, they naturally will continue to use the products/services regardless of their promotion or not. Loyal customers can also help the company become a marketer (agent) not paid considering they will provide recommendations or references to others in the form of word of mouth that is positive about the products/services they have used. 
Based on the description of the above variables influence between the frame of the research can be described as follows:

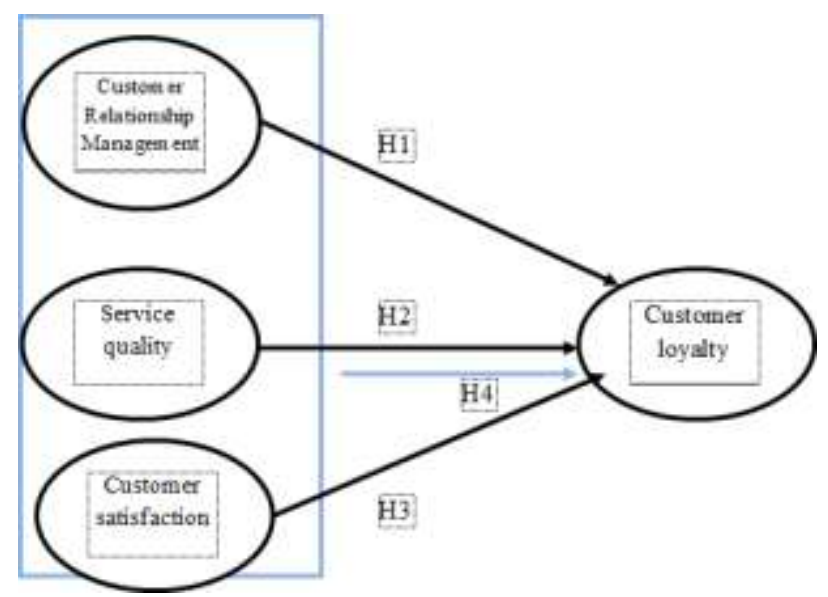

Picture 1. Conceptual Framework

\section{RESEARCH METHODS}

As this study is descriptive and verification, using the survey method. Neolaka (2014:

22) describes that descriptive research is generally done with the primary goal of systematically describe the facts and characteristics of the object and the subject under study accurately. Further relates to methods of survey, Morissan (2012: 165) suggests the survey is often used in the social sciences to help observe a social phenomenon. In the survey study, researchers chose some respondents in the sample and give them questioner is standard (default).

In this study, three instruments need to be made, namely instruments for measuring leadership, instruments for measuring the quality of services, instruments for measuring customer satisfaction, and an instrument to measure customer loyalty.

The following is a description of the population, sample testing, and sample:

Table 1. Population for sampling testing

\begin{tabular}{clccc}
\hline No. & $\begin{array}{l}\text { Branch office } \\
\text { PT. Al Badriyah Tourism }\end{array}$ & $\begin{array}{c}\text { population } \\
\text { Research }\end{array}$ & $\begin{array}{c}\text { Sample } \\
\text { Test }\end{array}$ & $\begin{array}{c}\text { Research } \\
\text { samples }\end{array}$ \\
\hline 1. & Pontianak & 373 & 6 & 20 \\
\hline 2. & Jambi & 15 & 1 & 1 \\
\hline 3. & Makassar & 96 & 2 & 5 \\
\hline 4. & Palembang & 33 & 1 & 2 \\
\hline 5. & Pekanbaru & 9 & 0 & 1 \\
\hline 6. & Surabaya & 142 & 2 & 7 \\
\hline 7. & Batam & 3 & 0 & 1 \\
\hline 8. & Bengkulu & 98 & 2 & 5 \\
\hline 9. & chili & 4 & 0 & 1 \\
\hline 10. & field & 4 & 0 & 1 \\
\hline 11. & Jakarta & 930 & 16 & 51 \\
\hline & Total & 1707 & 30 & 95 \\
\hline
\end{tabular}




\section{FINDINGS AND DISCUSSION}

Testing the hypothesis in this study using simple linear regression analysis to test the hypothesis of the first, second and third, as well as multiple linear regression techniques to test the fourth hypothesis. Analysis using SPSS Version 25. Both the analysis outlines the influence of each independent variable namely customer relationship management (X1), quality of service (X2), customer satisfaction (X3) on customer loyalty (Y).

Each variable in this study is the variable customer relationship management (X1), quality of service (X2), customer satisfaction (X3) and customer loyalty (Y) have been analyzed using descriptive statistical analysis and inferential statistical analysis.

\section{Effect of Customer Relationship Management on Customer Loyalty}

The results showed that the correlation coefficient X1 to Y (r) of 0.586. The correlation coefficient (r) that is positive, then the customer relationship management variables have a positive relationship with customer loyalty. The coefficient of determination (r2) of 0.344 has the meaning of customer relationship management variables contributed $34.40 \%$ to the change in customer loyalty. While the remaining $65.60 \%$ is contributed by other factors not examined in this study.

Furthermore, the customer relationship management tcount of 6.977 using a $95 \%$ confidence level $(\alpha=0.05)$, the obtained value ttabel is 1.986 . Referring to the significance value $0.000<0.05$ and tcount 6.977> 1.986 ttable it can be concluded that $\mathrm{H} 0$ rejected and $\mathrm{H} 1$ accepted, meaning that customer relationship management has a significant influence on customer loyalty.

While the results of the calculation of the amount of regression coefficient value of customer relationship management (X1) of 0.706 and a constant number of 17.630 pales in customer relationship management $(\mathrm{X} 1)$ value is 0 then the customer loyalty $(\mathrm{Y})$ value is 17.630. The regression coefficient variable customer relationship management (X1) of 0.706, meaning that if another independent variable value is fixed and customer relationship management $(\mathrm{X} 1)$ rose 1 point, then the customer loyalty $(\mathrm{Y})$ will increase by 0.706 . The coefficient is positive, meaning a positive influence on customer relationship management on customer loyalty, the greater the customer relationship management to further improve customer loyalty in the travel company organizing Umrah and Hajj PT. Travel Albadriyah.

Referring to the above results, it is proved that the dimension of partnering programs has been executed well by PT. Travel Albadriyah particularly for relations of cooperation to support an increase in customer loyalty. While the dimensions of continuity marketing especially about the ease of providing facilities need to get more attention from PT. Travel Albadriyah so that customer loyalty can be further improved.

These results indicate that the effect of customer relationship management on customer loyalty. This relationship can be interpreted that customer loyalty is influenced by changes in customer relationship management variables. Implications of the empirical research show that the higher the customer relationship management, the higher the customer loyalty in PT. Travel Albadriyah. 


\section{Effect of Quality of Service to Customer Loyalty}

The results showed that the correlation coefficient X2 to Y (r) of 0.681. The correlation coefficient ( $r$ ) that is positive, then the variable quality of service has a positive relationship with customer loyalty. The coefficient of determination (r2) of 0.464 has meaning service quality variables contributed $46.40 \%$ to the change in customer loyalty. While the remaining $53.60 \%$ is contributed by other factors not examined in this study.

Furthermore, the value of 8.969 t of service quality using a $95 \%$ confidence level $(\alpha=$ 0.05 ), the obtained value ttabel is 1.986. Referring to the significance value $0.000<0.05$ and tcount 8.969> 1.986 ttable it can be concluded that $\mathrm{H} 0$ rejected and $\mathrm{H} 1$ accepted, meaning that service quality has a significant influence on customer loyalty.

While the regression calculation results obtained by the value of the coefficient of quality of service (X2) of 0.545 and a constant number of 14.941 means that if the quality of service (X2) the value is 0 then the customer loyalty (Y) value is 14.941 . The regression coefficient service quality variables (X2) is 0.545 , meaning that if the other independent variables fixed value and quality of service (X2) rose 1 point, then the customer loyalty $(\mathrm{Y})$ will increase by 0.545 . The coefficient is positive, meaning a positive effect of service quality on customer loyalty, greater quality of service, the more increase customer loyalty in the travel company organizing Umrah and Hajj PT. Travel Albadriyah.

Variable quality of service is measured by five (5) dimensions namely tangible (physical evidence), reliability (reliability), responsiveness (responsiveness), assurance (assurance), and empathy (empathy). Based on the results of questionnaires, respondents about the variable quality of service has a score value of the average (mean) 3.93. If interpreted in a score per item question/statement of the average value (the mean) is in the category agree as it approaches the value of 4.

As for the value of the average score is the ultimate answer to the point statement KP7 (4.21) on employee travel umrah and hajj organizers provide clear information to pilgrims. KP7 point statement in the category of dimensions of responsiveness (responsiveness) with indicators providing information on services. As for the value of the average score of the lowest response was in the questions/statements KP8 (3.75) on employee travel umrah and hajj organizers able to provide security to the pilgrims during the journey. Point statement in the category dimension KP8 assurance (guarantee) with indicator guarantees for the safety during the trip.

Referring to the above results, it is proved that PT. Travel Albadriyah considered to have responsiveness (responsiveness) is good in serving pilgrims (customers) particularly about providing information on services. Meanwhile, about assurance (guarantee) specifically guarantees for the safety during the journey, pilgrims (customers) assess that PT. Travel Albadriyah still needs to pay attention to this matter so that customer loyalty can be improved.

\section{Effect of Customer Satisfaction to Customer Loyalty}

The results showed that the correlation coefficient X3 to $\mathrm{Y}(\mathrm{r})$ of 0.647 . The correlation coefficient ( $r$ ) that is positive, then the variable customer satisfaction has a positive relationship with customer loyalty. The coefficient of determination (r2) of 0.419 has meaning customer satisfaction variables contributed $41.90 \%$ to the change in customer 
loyalty. While the remaining $58.10 \%$ is contributed by other factors not examined in this study.

Furthermore, the value of $8,192 \mathrm{t}$ of customer satisfaction by using a $95 \%$ confidence level $(\alpha=0.05)$, the obtained value ttabel is 1.986 . Referring to the significance value 0.000 $<0.05$ and tcount 8,192>1,986 ttable it can be concluded that $\mathrm{H} 0$ rejected and $\mathrm{H} 1$ accepted, meaning that customer satisfaction has a significant influence on customer loyalty.

While the regression calculation results obtained by the value of the coefficient of quality of service (X2) is 0,746 and the number of constants of 5.325 pales customer satisfaction (X3) value is 0 then the customer loyalty (Y) value was 5.325. The regression coefficient customer satisfaction variable (X3) amounted to 0,746, which means that if another independent variable value is fixed and customer satisfaction (X3) rose 1 point, then the customer loyalty (Y) will increase by 0,746 . The coefficient is positive, meaning a positive effect on customer loyalty customer satisfaction, greater customer satisfaction, the more increase customer loyalty in the travel company organizing Umrah and Hajj PT. Travel Albadriyah.

Referring to the above results, it is proved that the pilgrims (customers) PT. Travel Albadriyah satisfied with the difference facilities offered by competitors. Meanwhile, about confirmation/disconfirmation pilgrims (customers) assess that PT. Travel Albadriyah still needs to be concerned about the suitability of the promised time. It is important that customer loyalty can be maintained.

\section{Effect of Customer Relationship Management, Service Quality and Customer Satisfaction to Customer Loyalty}

Based on calculations with SPSS version 25, it indicates that the correlation coefficient (r) customer relationship management (X1), quality of service (X2), customer satisfaction (X3) on customer loyalty (Y) of 0.762. The coefficient of determination (r2) of 0.567 has a variable meaning of customer relationship management, service quality, and customer satisfaction together contributed $56.70 \%$ to the change in customer loyalty. While the remaining $43.30 \%$ is contributed by other factors not examined in this study.

Referring to the significance value $0.000<0.05$ and value of $\mathrm{F} 42.004>2,70 \mathrm{~F}$ table it can be concluded that $\mathrm{H} 0$ rejected and $\mathrm{H} 1$ accepted, meaning that the customer relationship management, service quality, and customer satisfaction together have a significant influence on customer loyalty.

Based on the calculation, the regression equation $\mathrm{Y}=2.126+0.357 \mathrm{X} 1+0.265 \mathrm{X} 2+$ $0.323 \mathrm{X} 3$. The whole coefficient is positive, meaning a positive influence on customer relationship management, service quality, and customer satisfaction together on customer loyalty, greater customer satisfaction, the more increase customer loyalty.

These results indicate that customer relationship management, service quality, and customer satisfaction together affect customer loyalty. This relationship can be interpreted that the change in customer loyalty is influenced by variables of customer satisfaction. Implications of the empirical research show that the higher the customer relationship management, service quality and customer satisfaction, the higher the customer loyalty in PT. Travel Albadriyah 


\section{CONCLUSION AND SUGESTION}

Customer relationship management proved a positive and significant impact on customer loyalty in Corporate Travel Organizers Umrah and Hajj PT. Travel Albadriyah. It is most dominant in the form of customer relationship management is a partnering program dealing specifically with relations of cooperation. This shows that the larger the customer relationship management, the greater customer loyalty.

Quality of service proved positive and significant impact on customer loyalty in Corporate Travel Organizers Umrah and Hajj PT. Travel Albadriyah. It is most dominant in shaping the quality of service is responsiveness (responsiveness) particularly about providing information on services. This suggests that the greater the quality of service the greater the customer loyalty.

Customer satisfaction proved a positive and significant impact on customer loyalty in Corporate Travel Organizers Umrah and Hajj PT. Travel Albadriyah. It is most dominant in the form of customer satisfaction is the comparison particularly about the satisfaction of the different facilities of competitors. This suggests that greater customer satisfaction customer loyalty.

\section{REFERENCE}

Al-Arif, M. Nur Rianto. 2010. Marketing Basics Islamic Bank. Bandung: Alfabeta.

Amir, Mohammad Pour, Hajnazariheris Yousof, Ebrahimpour Asthma. 2014. The Effect of Using Customer Relationship Management System on Customer Loyalty, Case Study: Ansar Bank's Branches In East Azarbaijan. Indian J. Sci. Res. 8 (1): 098-106.

Ariani, D. Revelation. 2009. Management of Service Operations. Yogyakarta: Graha Science. Bransom, Robert. 2005. Customer Loyalty. Jakarta: Performance Library.

Darmawan, Deni. 2014. Quantitative Research Methods. Bandung: PT. Youth Rosdakarya

Dimyati, Johni. 2013. Educational Research Methodology and Applications In Early

Childhood Education (ECD). Jakarta: Kencana Prenada Media Group.

Dubery, Archi., AK Srivastava. 2016. Impact of Service Quality on Customer Loyalty, A

Study on Telecom Sector in India. IOSR Journal of Business and Management Volume 18 , Issue 2.

Durianto, S., 2010, Conquer Strategy Equity Research Through Market and Brand Behavior. Jakarta: PT. Gramedia Pustaka Utama.

Graha, I Made Satya. 2015. Effect of Service Quality on Customer Satisfaction and Loyalty of Hardy's Country. Thesis, University of Udayana.

Griffin, Jill. 2005. Customer Loyalty: How to Earn it, How to Keep it. Interpretation by Dwi Kartini Yahya. Jakarta: Erland.

Handoko, Hani T. 2002. Management. Yogyakarta: BPFE.

Hasan Ali. 2008. Marketing. Yogyakarta: Main Media.

Jafar, Farida. 2012. Theory and Applications Nine Keys to Success Business Services:

Human Resources, Innovation, and Customer Satisfaction. Jakarta: Four Salemba.

Egan, John. 2001. Relationship Marketing: Exploring Relational Strategies in Marketing.

London: Prentice-Hall.

Hollensen, Svend. 2003 Marketing Management: A Relationship Approach. New York:

Prentice-Hall. 
Kalalo, Rinny E. Kalalo. 2013. Customer Relationship Management and Service Quality Influence on Consumer Loyalty PT. Matahari Dept. Store Manado. EMBA Journal Vol. 1 No. 4.

Kertajaya, Hermawan. 2007. Boosting Loyalty Marketing Performance: Using Engineering Sales, Customer Relationship Management and Service to Boost Profit. Bandung: Mizan Pustaka.

Kocoglu, Duygu, Sevcan Kirmaci. 2012. Customer Relationship Management and Customer Loyalty: A Survey in the Sector of Banking. International Journal of Business and Social Science Vol. 3 No. 3.

Kotler, Philip. 2006. Marketing Management. New Jersey: Prentice Hall International, Inc.

Kotler, Philip, and Kevin Lane Keller. 2007. Marketing Management. Interpretation by Benjamin Molan. Jakarta: Index

Kotler, Philip, Kevin L. Keller. 2012. Marketing Management. New Jersey: Pearson Prentice Hall.

Kotler, Philip, Gary Armstrong. 2012. Principles of Marketing. New Jersey: Pearson Prentice Hall.

Kustini, Henny. 2017. Communication Skill. Yogyakarta: Deepublish.

Kuncoro, Mudrajat. 2001. The Theory and Application of Quantitative Methods for Business and Economics. Yogyakarta: UPP AMP YKPN.

Latan, Heng. 2014. Statistical Data Analysis for Social Studies of Science with STATA. Bandung: Alfabeta.

Leninkumar, Vithya. 2016. The Effect of Service Quality on Customer Loyalty. European Journal of Business and Management. Vol. 8 No. 33.

Lupiyoadi, Creep. 2006. Services Marketing Management: Theory and Practice. Jakarta: Four Salemba.

Maidi and Suwitho. 2014. Effect of Customer Relationship Management on Customer Loyalty PT. Moga Djaja in Surabaya. Journal of Management Studies and Research Vol. 3 No. 8.

Mudie, Peter, Angela Pirrie. 2006. Service Marketing Management. Burlington: Elsevier Ltd. Morissan. 2012. Survey Research Methods. Jakarta: Kencana Prenada Media Group.

Neolaka, Amos. 2014. Research Methods and Statistics. Bandung: PT. Youth Rosdakarya.

Newell, Frederick. 2000. Loyalty.com: Customer Relationship Management in the New Era of Internet Marketing. USA: Mc.Graw Hill.

Ningtias, Annisaa Ayu, Anindhyta Budiarti. 2017. Effect of Service Quality, Price, Customer Satisfaction, Customer Loyalty Tutoring against Alfagamma Surabaya. Journal of Management Studies and Research, Volume 6, Number 1.

Oktariana, Yuanira, Achmad Fauzi, Heroine Kumadji. 2012. Factors Customer Relationship Management (Customer Relationship Management) In Delivering Member Satisfaction and Its Impact on Member Loyalty (Survey on Cooperative Members Nusantara Branch Malang in Malang Post Office). Profit Journal Volume 6 No. 2.

Oliver, Richard L. 1999. WHENCE Consumer Loyalty? Journal of Marketing. Vol. 63 (Special Issue 1999) pp. 33-44. 
Rai, Alok Kumar, Medha Srivastava. 2013. The antecedents of Customer Loyalty: An Empirical Investigation in Life Insurance Context. Journal of Competitiveness, Vol. 5, Issue 2 June 2013.

Rianse, Usman., Abdi. 2008. The methodology of Social and Economic Research. Bandung: Alfabeta.

Robinette, Scott. 2001. Emotion Marketing. Jakarta: Mc.Graw Hill Companies Inc.

Schiffman, Leon G, Leslie L. Kanuk. 2007. Customer Behavior. New Jersey: Pearson Education Inc.

Seravine, Ignatia Alfani. 2016. Effect of Service Quality, Trust, Complaints and Customer Satisfaction to Customer Loyalty Workshop Toyota Nasmoco Solo Baru. Thesis, University of Atma Jaya Yogyakarta.

Setiyawati, Antari. Customer Satisfaction Study 2009. To Achieve Customer Loyalty (A Case Study of Consumer Stores Building Build fortune Semarang). Thesis, University of Diponegoro,

Sheth, Jagdish N., Atul Parvatiyar, G. Shainesh. 2001. Customer Relationship Management, Emerging Concepts, Tools and Applications. New Delhi: Tata McGraw-Hill Publishing Company Limited.

Stanton, W. 2004. Fundamentals of Marketing. New York: McGraw Hill Companies Inc.

Storbacka, Kaj, Jarmo R. Lehtinen, 2001. Customer Relationship Management: Creating

Competitive Advantage Through Win-Win Relationship Strategies. Singapore: McGraw Hill.

Sudarso, Andriasan. 2016 Marketing Management Hospitality Services. Equipped With RESEARCH In rated hotels in North Sumatra. Yogyakarta: Deepublish.

Sugiyono. 2010. Quantitative Approach Educational Research Methods, Qualitative and R \& D. Bandung: Alfabeta.

Sugiyono. 2014. Research Methods in Management. Bandung: Alfabeta.

Suliyanto. 2005. Analysis of Data In Applications Marketing. Bogor: Ghalia Indonesia.

Supranto, J. 2001. Measuring Customer Satisfaction Levels To Increase Market Share.

Jakarta: PT. Rineka Reserved.

Suryani., Hendryadi. 2016. Quantitative Research Methods: Theory and Applications In

Research in Management and Economics of Islam. Jakarta: Prenadamedia Group.

Swastha, Basu. 2002. Principles of Marketing. Yogyakarta: Liberty.

Tahuman, Zainuddin. 2016. Analysis of Factors Influencing Customer Loyalty And Its Impact on Competitive Advantage. Journal of Business Research and Management Vol. 4, No. 3 Special Edition Marketing \& Finance, 2016.

Tiwana, Amrit. 2001. The Essentials Guide to Knowledge Management: E-Business and CRM Applications. USA: Prentice-Hall.

Tjiptono, Fandy, Gregory Chandra. 2011. Service, Quality \& Satisfaction. Yogyakarta: Andi. Tjiptono, Fandy. 2007. Marketing Services. Malang: Bayumedia Publishing

Tjiptono, Fandy. 2014 Services Marketing, Principles, Application and Research. Yogyakarta: Andi.

Utomo, Priyanto Doyo. 2006. Analysis of Factors Affecting Consumer Loyalty In Mobile Phone Operator. Thesis: University of Gadjah Mada. 
Wantara, Pribanus. 2015. The Relationships Among Service Quality, Customer Satisfaction, and Customer Loyalty in Library Services. International Journal of Economics and Financial Issues, Vol. 5, Special Issue.

Widadi, Rima Hayu Sri Farid Wadji. 2015. Factors Influencing the Customer Loyalty Clinical Neuroscience Regional Mental Hospital Dr. RM Soedjarwadi. Journal of Economic Competitiveness Resource Management Vol. 17, No. 1, June 2015.

Wilkie, WL 1994. Customer Behavior. New York: John Wiley \& Sons, Inc.

Yazid. 2005. Marketing Concepts and Implementation Services. Yogyakarta: Ekonisia.

Zeithaml, Valarie A., Mary Jo Bitner, Dwayne D. Gremler. 2006. Services Marketing, Integrating Customer Focus Across the Firm. New York: McGraw Hill.

Zulganef. 2008. Methods of Social Research and Business. Yogyakarta: Graha Science.

Other sources:

Haji Reality magazine in 2011

Data from the Ministry of Religion Year 2017 